\section{Discurso de \\ posse do novo \\ diretor do INPA}

Exmo. Sr. Governador em exercício Paulo Pinto Nery Exmo. Sr. Prof. Dr. Maurício Matos Peixoto

Ilmo. Sr. Prof. Dr. José Alberto Sampaio Nunes de Mello

Autoridades civis e militares

Senhores e Senhoras

Há aproximadamente 10 anos iniciei meu trabalho de pesquisa na região amazônica.

De inicio, impressionou-me o volume imenso das águas que correspondem a $20 \%$ da reserva de água doce líquida do planeta Terra. Em seguida, o complexo dos ecossistemas nos seus mais variados aspectos, o solo, as plantas e a vida animal prenderam minha atenção, e, finalmente, o povo, das mais diversas camadas da estrutura social, aguçou-me a curiosidade pelo heroismo na contínua luta de sobrevivência nesta regiấo.

A medida em que os estudos avançavam, pouco a pouco senti que a floresta rude e a imensidão das águas, embora aparentemente se apresentassem como estrutura indestrutivel, não passavam na realidade de um frágil sistema que os séculos através de uma luta contínua e constante conseguiram criar.

A hiléia assim foi vista por mim, como um frágil organismo necessitando de especiais cuidados, a fim de que o equilibrio secular que ora existe não seja totalmente perturbado pela ação inconsciente de um desenvolvimento não programado e de uma atividade econômica que visa lucros a curto prazo.

Embora nossa ignorância, em relação aos múltiplos problemas, ainda seja muito grande, a experiência acumulada através de centenas de pesquisadores e do conhecimento popular, que tão sabiamente analisa a natureza, permite hoje estabelecer alguns pontos positivos do conhecimento humano sohre o complexo sistema amazônico.

Estes conhecimentos permitem definir em linhas claras e seguras os proplemas que serão enfrentados, por nós, e pelas gerações futuras, se precauções especiais nâo forem tomadas durante a ocupação desta área.

Só para tocar nos problemas mais relevantes, quer pela qualidade, quer pela extensão que apresenta, gostaria de lembrar:

1. O sistema amazônico no que diz respeito ao balanço hídrico, encontra-se num estado de equilíbrio dinâmico, sendo que as chuvas são produzidas aproximadamente $50 \%$ com o vapor primário proveniente dos oceanos e os outros $50 \%$ sendo produzidos pela recirculação das águas. Neste processo, a floresta tem um papel fundamental, fornecendo através da transpiração 
das plantas o vapor necessário para que este equilibrio seja mantido. Além disso, funciona ainda a cobertura vegetal como uma determinante do tempo médio de residência da água nas diversas bacias hidrográficas;

2. Existe uma relaçăo de interdependência, cujas magnitudes são ainda desconhecidas entre os parâmetros do clima do planalto Central Brasileiro com as características das massas de ar sobre a região amazônica;

3. As atividades humanas já romperam o equilíbrio do ciclo do gás carbônico no nosso planeta. O teor deste gás está aumentando, nos últimos 30 anos, a uma taxa de uma parte por milhão por ano. As atividades responsáveis por este desequilibrio são a queima de combustíveis fósseis, petróleo em especial, e a destruição das florestas;

4. Os solos da Amazônia, geralmente com baixa fertilidade, suportam a floresta através de um delicado sistema de reciclagem dos nutrientes vegetais. O reservatório destes nutrientes está realmente na biomassa da própria floresta, que através da sábia lei das compensações mantém-se verde e exuberante como a conhecemos. Este equilibrio é permitido pela participação das múltiplas espécies vegetais, que associadas à vida animal nas suas diversas formas, decompōe e recicla os elementos químicos, sendo que neste processo o universo dos microorganismos representa um relevante papel;

5. A vida aquática nos seus multiformes aspectos faz da bacia amazônica uma das mais piscosas do mundo. Os seus peixes, de qualidade superior para alimentação, dependem para sobreviver de uma complexa inteiração entre o solo, a floresta e as águas. Medidas contínuas detectaram que a população de peixes da Amazônia está diminuindo, e por experiências já vividas em outras regiões do Brasil e do mundo, sabe-se que a modificação de qualquer elemento da cadeia alimentar provoca a extinção de muitas espécies;

6. As observações indicam que, desde o início da colonização do continente, os homens que aqui habitavam possuiam uma vida boa e tranquila dentro dos problemas característicos da vida selvagem. As pesquisas atuais encontram toda uma conjuntura difícil e de futuro ignorado para os índios que habitam esta região. O impacto da civilização sem o carinho e a compreensão, por certo destruirá os hábitos simples e puros do povo das nossas matas. tinentes :

Diante destas informações, algumas recomendações são per-

a. Avaliar nos seus diversos aspectos e da maneira mais ampla possível, os sucessos e os problemas nas áreas da Amazônia, recentemente ocupada pelos diferentes sistemas de coloniza. ção; 
b. Rever a legislaçăo existente e fazer uma pausa para meditação até que os órgãos responsáveis estejam aparelhados para orientar e vigiar a ocupaçăo de novas áreas;

c. A definição de "recursos renováveis" precisa ser melhor caracterizada - o ecossistema amazônico não é um recurso renovável. Como qualquer organismo vivo, ele possui um poder de regeneração, no entanto, à medida que o trauma vai crescendo, mais difícil se torna a recuperaçáo. Há ainda que se definir a escala do tempo para a renovação desses recursos - estamos falando em dezenas, centenas ou milhares de anos, dependendo da dimensão das alterações provocadas;

d. O custo da exploração dos recursos florestais deve ser feito incluindo o preço do reflorestamento e da conservação da natureza. Tendo em vista que grande parte do problema é gerado durante a retirada das árvores adultas, pois neste processo destrói-se pelo impacto ou pelo fogo as árvores jovens e a vida animal, talvez não seja um sonho a utilização de métodos sofisticados na retirada das árvores. Destes, até a utilização de dirigiveis tem sido mencionada;

e. O planejamento, para qualquer finalidade, deve ser feito tendo por base a baćia hidrográfica na sua menor caracterização. A conservação do solo deve ser a tônica mais importante do planejamento;

f. Fomentar e desenvolver a agricultura das várzeas, deve ser um dos pontos prioritários do planejamento;

g. Conservar as matas, em faixas amplas contornando rios, igarapés e lagos e, ainda, conservar no mínimo $60 \%$ da mata em faixas alternadas ao longo das curvas de nível, deve ser a meta inicial.

Diante da problemática indicada e das recomendações iniciais, apenas esboçadas em forma geral, percebe-se quais as linhas de pesquisa que, se desenvolvidas daqui para frente, deverão lançar luzes esclarecedoras, a fim de que os homens responsáveis pelo planejamento da ocupação do território nacional, possam encontrar apoio para a ação, baseando-se em informações cientificas, técnicas e humanas.

Assim, a atuação do INPA, através dos seus organismos em diversas partes da região, deverá desenvolver um trabalho de dimensões que às vezes me assusta.

Pesquisas Básicas - fundamentais para o conhecimento dos fenômenos mais diversos, terão que ser incrementadas nos aspectos físico, químico e biológico.

Pesquisas Tecnológicas - procurando resolver problemas imediatos, necessitam ser aceleradas, especialmente no campo das alternativas de fontes de energia. 
Pesquisas Ecológicas e Agronômicas - que permitam delineamento de utilização dos recursos naturais deverão, a curto prazo, receber o necessário impulso para que permitam uma produção de alimentos dentro de um sistema ecológico equilibrado

$E$, finalmente,

Pesquisas Médicas e Sociais - para proporcionar ao povo meIhor condição de vida, necessitam de urgente amparo.

Analisando esta vasta rede de atividades que será necessária c que terá que ser desenvolvida pelo INSTITUTO NACIONAL DE PESQUISAS DA AMAZONIA, é que percebo a necessidade de contar com o apoio irrestrito das autoridades civis e militares, das universidades e de todos os organismos estaduais e federais que atuam na região, a fim de que possamos unir esforços, cumprindo nossa missão de estabelecer melhores condições de vida para o nosso povo.

E para completar, gostaria de relatar um estudo que me chamou atenção, realizado na aldeia dos Kayapó. Concluiu-se que esses índios utilizam $10 \%$ de seu tempo procurando alimentos através de atividades de agricultura, caça e pesca, e que o restante do tempo é utilizado em jogos e nos exercícios do amor.

O que eu gostaria de saber é se a nossa civilização, algum dia, poderá trazer de novo, ao homem moderno, a mesma felicidade!

Eneas Salati 